\title{
Mate choice and reproductive success of two morphs of the seven spotted ladybird, Coccinella septempunctata (Coleoptera: Coccinellidae)
}

\author{
SHEFALI SRIVASTAVA and OMKAR* \\ Ladybird Research Laboratory, Department of Zoology, University of Lucknow, Lucknow-226007, India
}

Key words. Ladybird, Coccinella septempunctata, melanic, typical, mate choice, reproductive success, age specific fecundity

\begin{abstract}
Mate choice, reproductive success and fecundity of typical and melanic morphs of C. septempunctata were studied. Melanic as well as typical individuals preferred to mate with melanic males and females. Mate choice was mainly determined by females and to a lesser degree by males. Mating duration, oviposition period, and lifetime fecundity were highest $(51.20 \pm 2.82 \mathrm{~min}$, $47.00 \pm 2.79$ days and $705.40 \pm 69.85 \mathrm{eggs})$ when a melanic female mated with a melanic male and lowest (38.94 $\pm 1.68 \mathrm{~min}, 26.10$ \pm 2.54 days, $395.9 \pm 36.25$ eggs) when a typical female mated with a typical male. Longevity of both sexes of melanics was higher than of typicals. The fecundity function of both morphs was triangular but the daily oviposition was irregular. In melanic and typical females the peak oviposition (66.40 eggs/day and 48.30 eggs/day) occurred on the $23^{\text {rd }}$ and $14^{\text {th }}$ day of the oviposition period, respectively. Oviposition peaked earlier in typical females, but peak oviposition was higher and the oviposition period longer in melanic females. The higher reproductive success of melanics may favour this morph over typicals.
\end{abstract}

\section{INTRODUCTION}

Non-random mating is a common phenomenon in insects, with mate choice dependent on a number of factors such as morphology (Majerus et al., 1982a, b; Wang, 2002), age (Hansen \& Price, 1995; Kokko \& Lindstrom, 1996) and/or mating status (Sakaluk \& Ivy, 1999; Savalli \& Fox, 1999; Sakaluk et al., 2002). Although sexual activity per se has received less attention in ladybirds, the phenomenon of non-random mating or mate choice has been studied, in polymorphic species, which are convenient experimental models (Hodek \& Ceryngier, 2000).

Polymorphism in ladybirds is based on the degree of melanism of species-specific elytral patterns. Based on the number of spots, stripes, their fusion or absence, ladybirds have been grouped into pale, typical and melanic morphs (Hodek \& Honěk, 1996). Such is the degree of variability that morphs of a highly polymorphic ladybird, Harmonia axyridis (Pallas), were previously considered to be different species or even genera (Komai, 1956). Adalia bipunctata (Linnaeus) is another highly polymorphic species (Majerus et al., 1982a, b). A population of a dimorphic species, Coccinella septempunctata Linnaeus contains typical (having seven distinct black spots) and melanic (fused black spots) morphs (Rhamhalinghan, 1985, 1987).

Other than the morphological differences (elytral patterns), life history characters, such as reproductive performance (Brakefield, 1984a, b, c) and adaptations to different climatic conditions (Komai, 1956; De Jong \& Brakefield, 1998; Soares et al., 2001) also vary between morphs. Though more active and fecund than typicals (Rhamhalinghan, 1987), melanic C. septempunctata are less common in the fields which is surprising.
Studies on mate choice or non-random mating in polymorphic ladybirds have generally claimed that melanics are preferred over typicals as mates (Lusis, 1961; Muggleton, 1979; Majerus et al., 1982a; Osawa \& Nishida, 1992), although not consistently so (Creed, 1975; Brakefield, 1984c; Kearns et al., 1990, 1992).

Though mate choice has been studied in ladybirds (Creed, 1975; Majerus et al., 1982a; Hemptinne et al., 1998; Kearns et al., 1990, 1992) the mating behaviour of C. septempunctata has been little studied. A recent study on C. septempunctata describes its courtship and mating behaviour (Omkar \& Srivastava, 2002). The life histories of the different morphs are rarely studied, although a few such studies on C. septempunctata exist (Rhamhalinghan, $1985,1987)$. However, there is no information on its agespecific fecundity, which is well studied in a few other ladybirds (Ponsonby \& Copland, 1998; Dixon \& Agarwala, 2002; Omkar \& Pervez, 2002).

The present study was therefore designed: (1) to study mate choice of the different morphs of both sexes of $C$. septempunctata, (2) to understand the significance of mate choice by investigating the reproductive responses viz. pre-oviposition, oviposition, and post-oviposition periods, fecundity and hatching success of eggs of homomorphic and heteromorphic pairs, and (3) to study age specific fecundity of typicals and melanics.

\section{MATERIAL AND METHODS}

\section{Maintenance of stock}

The two morphs of C. septempunctata along with the aphid, Aphis craccivora Koch, were collected on plants of Dolichos lablab Linnaeus growing in agricultural fields near Lucknow (India) and reared in the laboratory $\left(25 \pm 2{ }^{\circ} \mathrm{C}, 60 \pm 5 \%\right.$ R.H and $12 \mathrm{~L}: 12 \mathrm{D}$ photoperiod). Adults of the same colour morph were

\footnotetext{
* Corresponding author; e-mail: omkaar55@hotmail.com
} 
TABLE 1. Mate choice of the two morphs of both sexes of Coccinella septempunctata.

\begin{tabular}{cccc}
\hline \multicolumn{3}{c}{ Mating observed } \\
\hline Number of typical females & typical female $\times$ melanic males & typical female $\times$ typical males & Significance \\
36 & 25 & 11 & $\chi^{2}=5.44 ; \mathrm{P}<0.05$ \\
Number of melanic females & 27 & 9 & $\chi^{2}=9.00 ; \mathrm{P}<0.001$ \\
36 & 23 & 13 & Significance \\
\hline Number of typical males & typical males $\times$ melanic females & typical males $\times$ typical females & $\chi^{2}=2.78 ; \mathrm{P}<0.10$ \\
36 & 24 & 12 & $\chi^{2}=4.00 ; \mathrm{P}<0.05$ \\
\hline
\end{tabular}

paired and allowed to mate. Eggs were collected and reared from egg hatch to adult emergence in glass beakers $(11.0 \times 9.0$ $\mathrm{cm})$. The larvae were supplied daily with an excess of $\mathrm{A}$. $\mathrm{crac}-$ civora on D. lablab. Emerging adults were sexed and different morphs separated.

\section{Experimental setup}

Mate choice

Ten-day-old unmated melanic and typical males of C. septempunctata were measured and weighed to assess the role of male size in mate choice. Males and females were paired with either of the two morphs for $60 \mathrm{~min}$ to observe the morph-dependent choice of mates. Thirty-six replicates of each combination were observed. Numbers in each combination for mating were recorded; the data analyzed by Chi square $\left(\chi^{2}\right)$ test, and percent mating with different morphs calculated.

Reproductive attributes of typical and melanic morphs

In an attempt to explain the mate choice revealed by the experiment described above, ten-day-old adults were paired from 10.00 a.m. to 6.00 p.m. in four combinations: (i) melanic male and typical female, (ii) typical male and melanic female, (iii) melanic male and melanic female, and (iv) typical male and typical female. The pairs were allowed to mate and the sexes separated after mating. Each pair was allowed to mate five times. Several parameters were assessed, viz. mating duration (time from intromission until dismounting), latent period (time between intromission and first abdominal shaking), bouts (lateral abdominal shaking of male during mating) and bout rate (number of bouts per min). This was recorded for ten different pairs.

The pre-oviposition (period between emergence and first oviposition), oviposition (period from first oviposition to last oviposition) and post-oviposition periods (period from last oviposition to death), fecundity, percentage egg hatch and longevity of males and females were recorded (mean \pm S.E.). Results were tested and found to be normally distributed. Results on longevity were subjected to One-way ANOVA to test whether the means of two populations (melanics and typicals) were equal. Pre-oviposition, oviposition and post-oviposition periods, fecundity and percentage of egg hatch were subjected to Two-way
ANOVA, with sex of the adults as the column factor and morph as the row factor.

Age specific fecundity of typical and melanic morphs

Newly emerged males of both morphs were paired with the females of same morph in Petri dishes $(9.0 \times 1.5 \mathrm{~cm})$ and reared on A. craccivora until the death of the female ladybird. Results on oviposition and age-specific fecundity were recorded and the trend lines plotted using the statistical package MINITAB $(\mathrm{n}=$ 10).

\section{RESULTS}

\section{Mate choice}

Typical males were bigger and heavier $(6.17 \pm 0.37 \mathrm{~mm}$ and $31.56 \pm 6.14 \mathrm{mg})$ than melanic males $(6.00 \pm 0.53$ $\mathrm{mm}$ and $29.93 \pm 2.14 \mathrm{mg})$. Both typical $\left(\chi^{2}=5.44 ; \mathrm{df}=1\right.$; $\mathrm{P}<0.05)$ and melanic females $\left(\chi^{2}=9.00 ; \mathrm{df}=1 ; \mathrm{P}<\right.$ $0.001)$ preferred melanic to typical mates. Similarly, both typical $\left(\chi^{2}=2.78 ; \mathrm{df}=1 ; \mathrm{P}<0.10\right)$ and melanic males $\left(\chi^{2}\right.$ $=4.0 ; \mathrm{df}=1 ; \mathrm{P}<0.05)$ preferred melanic to typical females (Table 1). A total of $81.48 \%$ of the melanic males and $51.85 \%$ of the typical males mated. The percentage of melanic and typical males that mated differed significantly $(\mathrm{U}=57.0, \mathrm{P}<0.005)$.

\section{Reproductive attributes of typical and melanic morphs}

Unmated melanic males $(\mathrm{F}=9.64 ; \mathrm{df}=1,18 ; \mathrm{P}<$ $0.005)$ and females $(\mathrm{F}=12.85 ; \mathrm{df}=1,18 ; \mathrm{P}<0.005)$ lived significantly longer than the corresponding unmated sexes of typicals, but the life spans of the males and females of each morph did not differ significantly (Table 2) (Fig. 1).

Mating duration was longest $(51.20 \pm 2.82 \mathrm{~min})$ when melanic individuals mated, and shortest (38.94 \pm 1.68 min.) when typical individuals mated. Latent period was longest $(5.13 \pm 0.24 \mathrm{~min})$ when a typical male mated with a melanic female, and shortest $(4.62 \pm 0.38 \mathrm{~min})$ when a

TABLE 2. Longevity of unmated adults of both morphs of Coccinella septempunctata $(\mathrm{n}=10)$.

\begin{tabular}{lccc}
\hline & Melanic male & Melanic female & \\
Longevity (in days) & $75.70 \pm 2.30$ & $70.40 \pm 1.33$ & $\mathrm{~F}=3.64 ; \mathrm{P}<0.1$ \\
& Typical male & Typical female & \\
Longevity (in days) & $66.00 \pm 1.90$ & $63.10 \pm 1.42$ & $\mathrm{~F}=2.18 ; \mathrm{P}<0.1$ \\
& $\mathrm{~F}=9.64 ; \mathrm{P}<0.005$ & $\mathrm{~F}=12.85 ; \mathrm{P}<0.005$ & \\
\hline
\end{tabular}

Data mean \pm S.E. 


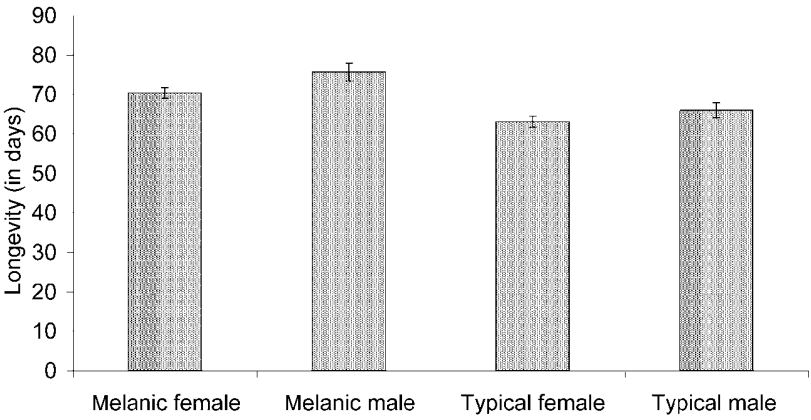

Fig. 1. Longevity of males and females of typical and melanic morphs of $C$. septempunctata.

melanic male mated with a melanic female (Fig. 2). Bout rates of melanic males mating melanic females were higher than that of matings between typical males and females (Fig. 3). The pre-oviposition period was longest (16.00 \pm 0.64 days) when a typical female mated with a melanic male and shortest $(13.00 \pm 0.64$ days $)$ when a melanic male mated with a melanic female. The oviposition period of melanic females was longest (47.00 \pm 2.79 days) when mated with melanic males and shortest (26.10 \pm 2.54 days) when a typical female mated a melanic male. The post-oviposition period of typical females mated with melanic males and was shorter $(8.9 \pm 1.40)$ than that of typical female mated with typical male $(15.1 \pm 1.79)$ (Fig. 4). Fecundity was highest $(705.40 \pm 69.85$ eggs $)$ when melanic females were paired with melanic males and lowest when typical females $(395.90 \pm 36.25$ eggs $)$ were paired with melanic males. The percentage of eggs that hatched was highest for melanic female $(93.26 \pm 1.20)$ mated with typical male and lowest for typical female (92.04 \pm 1.43$)$ mated with melanic males (Fig. 5).

Two-way ANOVA revealed that mating duration $(\mathrm{F}=$ $0.55 ; \mathrm{df}=1,37 ; \mathrm{P}<0.1)$, bout rate $(\mathrm{F}=0.6 ; \mathrm{df}=1,37 ; \mathrm{P}<$ $1)$, pre-oviposition period $(\mathrm{F}=0.545 ; \mathrm{df}=1,37 ; \mathrm{P}<1)$, oviposition period $(\mathrm{F}=0.38$; $\mathrm{df}=1,36$; $\mathrm{P}<1$ ), postoviposition period $(\mathrm{F}=0.70 ; \mathrm{df}=1,36 ; \mathrm{P}<1)$ and fecundity $(\mathrm{F}=0.23$; df $=1,1,37 ; \mathrm{P}<1)$ were not significantly affected by male morph. However, mating duration $(\mathrm{F}=$ 21.98; df $=1,37 ; \mathrm{P}<0.001)$, bout rate $(\mathrm{F}=13.1 ; \mathrm{df}=$ $1,37 ; \mathrm{P}<0.005)$, pre-oviposition period $(\mathrm{F}=8.73$; $\mathrm{df}=$

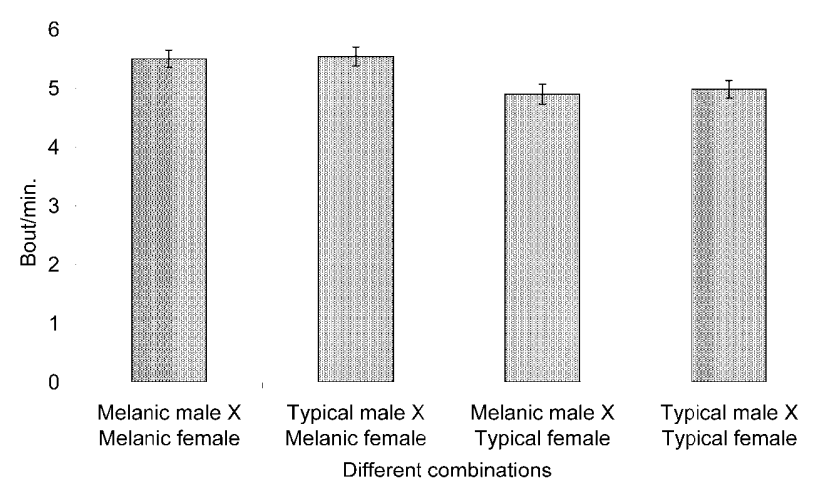

Fig. 3. Bout rate when the two morphs of $C$. septempunctata mated with either melanic or typical males.

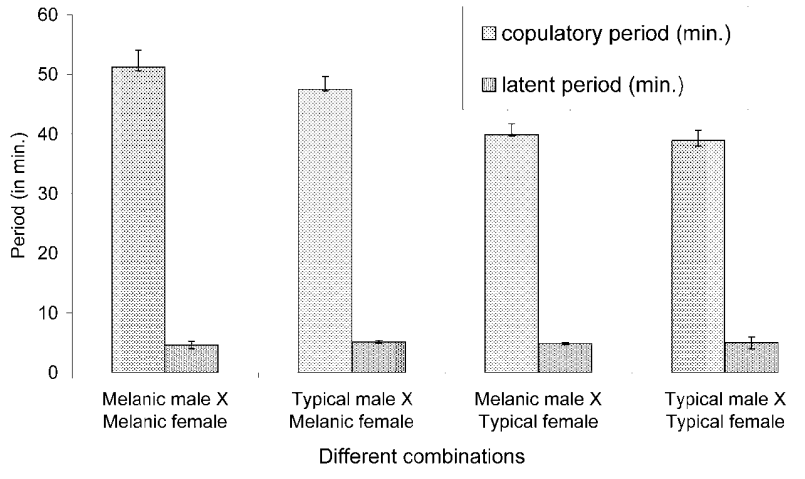

Fig. 2. Copulatory and latent period of the two morphs of $C$. septempunctata mated with either melanic or typical males.

$1,37 ; \mathrm{P}<0.005)$, oviposition period $(\mathrm{F}=32.01 ; \mathrm{df}=1,36$; $\mathrm{P}<0.01)$, post-oviposition period $(\mathrm{F}=4.81 ; \mathrm{df}=1,36 ; \mathrm{P}$ $<0.05)$ and fecundity $(\mathrm{F}=35.4 ; \mathrm{df}=1,37 ; \mathrm{P}<0.001)$ were significantly affected by female morph.

Latent period and percentage of egg hatch were not affected by sexes $(\mathrm{F}=1.81 ; \mathrm{df}=1,37 ; \mathrm{P}<0.2 ; \mathrm{F}=0.62$; $\mathrm{df}=1,37 ; \mathrm{P}<1)$ or morph $(\mathrm{F}=0.02 ; \mathrm{df}=1,37 ; \mathrm{P}<1 ; \mathrm{F}=$ $0.97 ; \mathrm{df}=1,37 ; \mathrm{P}<1)$ of the parents.

\section{Age specific fecundity}

Fig. 6 reveals that the daily oviposition rate increased with increase in age, reached a peak and then slowly decreased in females of both morphs. For melanic females, a peak of 66.40 eggs/day was attained on the 23 rd day of oviposition and for typical females, it was of 48.30 eggs/day on the 14 th day of oviposition. C. septempunctata did not lay eggs daily. The inter-oviposition periods ranged from 0-5 days for both morphs. Age specific fecundity of both morphs was triangular but erratic because of the inter-oviposition periods. Although the peak in oviposition of typical females occurred earlier than that of melanic females their oviposition period was longer.

\section{DISCUSSION}

Mating is costly in terms of energy and time for both sexes. The costs are generally greater for females than for

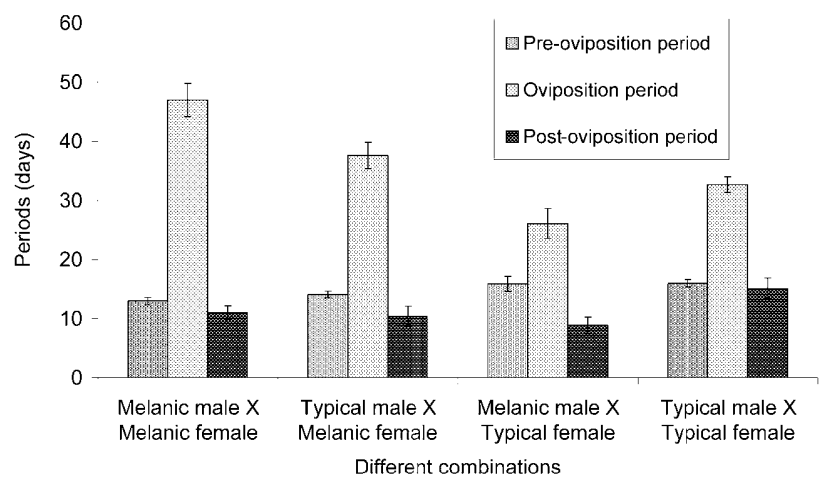

Fig. 4. Reproductive and non-reproductive periods of the two morphs of $C$. septempunctata mated with either melanic or typical males. 


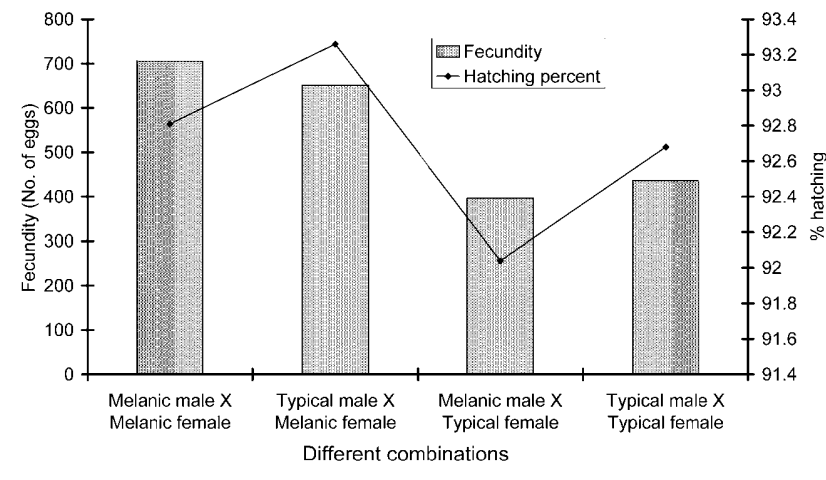

Fig. 5. Fecundity and percentage of egg hatch of the two morphs of C. septempunctata mated with either melanic or typical males.

males since females produce large, heavily resourced gametes, while males produce small gametes (Majerus, 1997). Hence, evolution should promote female choice and evidence for this was provided by Darwin (1871).

Earlier studies suggested that mate choice in insects is not advantageous because: (i) if the preferred phenotype is rare it will take more time and energy to find a mate (Majerus et al., 1982a), and (ii) for male insects reproductive success is determined more by the insemination of a large number of females and less by the quality of the females inseminated (Thornhill \& Alcock, 1983). But the existence of mate choice is now a well-accepted and researched phenomenon in insects (Majerus et al., 1982a; Hansen \& Price, 1995; Kokko \& Lindstrom, 1996; Jennions \& Petrie, 1997).

The occurrence of mate choice and the quest to understand its evolutionary significance has prompted several theories: (1) Mate choice is sensory and involves behavioural responses to certain phenotypes (Jennions \& Petrie, 1997); (2) it may be frequency dependent (O'Donald \& Majerus, 1984, 1985; Osawa \& Nishida, 1992) and/ or (3) female choice could be genetic (Fisher, 1930; Majerus et al., 1982b).

Two contradictory models of age dependent mate preference (Hansen \& Price, 1995; Kokko \& Lindstrom, 1996) unite in the view that selection for a particular phenotype or genotype is based on the purported advantages that mating will bestow on them. Similar reasons for the preference for virgin over non virgins mates have been previously discussed in terms of decline in nutritional gain by females when mated with non virgins rather than virgin males (Jennions \& Petrie, 1997; Savalli \& Fox, 1999).

Our results show a preference for melanic mates by both typical and melanic females, and males, which may be attributed to the better performance of melanics. A similar preference for melanics is recorded for other ladybirds (Majerus et al., 1982a; Ueno et al., 1998). It was earlier suggested that mate preference is not morph dependent but a frequency dependent phenomenon in which the rare morph in a population is preferred over the common one (Muggleton, 1979). This dependence on frequency probably leads to the maintenance of variation in

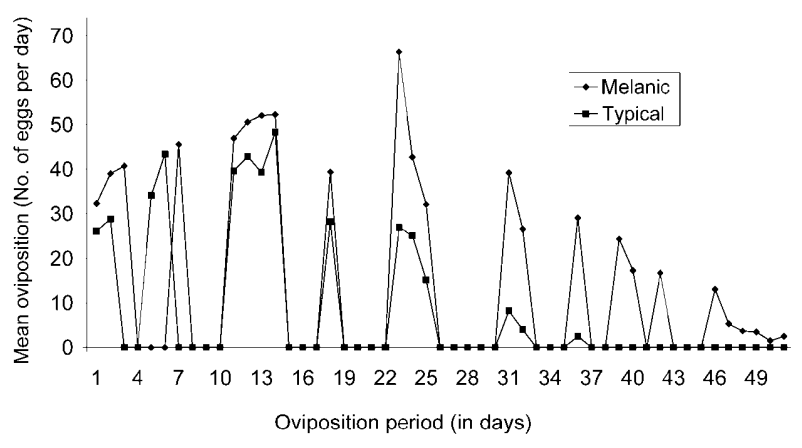

Fig. 6. Age specific fecundity of melanic and typical morphs of C. septempunctata.

nature (Muggleton, 1979; O’Donald \& Majerus, 1984). Mate choice has also been seen as a seasonal phenomenon (Osawa \& Nishida, 1992) with light males preferred in spring and dark males more successful in summer (Creed, 1975). These studies reject the mating preference phenomenon and frequency dependent advantage of melanic morphs (Kearns et al., 1992).

Females showed a more pronounced mate choice than males possibly because of the lower advantage of mate choice for males. The preferential matings confirm the earlier reports that the females of some coccinellids species (A. bipunctata and $H$. axyridis) do not mate at random but prefer certain males (Rothschild \& Lane, 1962; Hodek \& Ceryngier, 2000). Female preference for certain males supports the idea of Darwin (1871) and Fisher (1930) of sexual selection by choosy females. Many reasons are proposed for female choice as (1) females tend to mate with males better adapted to local conditions (Proulx, 2001), (2) condition dependent mating success, in which females prefer males, raised under better conditions (Merkel, 1977; Simmons, 1987), (3) mate choice is genetic and uninfluenced by male competition (Majerus et al., 1982b), and/or (4) females make the choice to contribute a greater proportion of offspring to future generations by choosing a male, which possesses a selective advantage in nature (Majerus et al., 1982a). Hence it may be inferred that female preference and not male competitiveness has indeed been selected for which conforms with Hodek \& Ceryngier (2000) view. Earlier, colour of the elytra was also assumed to be an important factor in the selection of mates by females as mate choice is also known to depend on visual or olfactory recognition (Hodek \& Ceryngier, 2000; Omkar \& Srivastava, 2002). The presence of species specific surface alkanes on elytra (Hemptinne et al., 1998) have raised questions about the possible presence of sex and morph specific alkanes, which might aid in the recognition and thus preference for a particular morph (Hodek \& Ceryngier, 2000). Scanning electron microscopic studies revealed numerous sensillae, viz., chaetica, trichoidea, basiconica and ampucellacea, on the antennae of C. septempunctata, which function as mechano-, tactile, olfactory etc., receptors and might help in mate choice (Srivastava \& Omkar, 2003). 
The preference for melanics might also be a consequence of their higher body temperature at low light intensities, as suggested by biophysical models (Muggleton et al., 1975; Brakefield \& Willmer, 1985). Body temperature affects activity and predatory potential, and probably also mate choice (Muggleton et al., 1975; Brakefield \& Willmer, 1985). However, Lusis (1961) states that if mate choice is frequency dependent then there would be no advantage in melanics being more active.

That melanic males had higher mating percentage than typical males may be attributed to their smaller size and lower weight, as small males are more successful than the larger males at mating under conditions of food deprivation (Yasuda \& Dixon, 2002). However, the earlier studies of Ueno et al. (1998) indicate that large males are more successful at mating than small males.

The enhanced reproductive success, in terms of long oviposition period and fecundity, of melanic C. septempunctata accords with the findings of Rhamhalinghan (1987). This enhanced reproductive success of melanics may affect their attractiveness as mates. The higher body temperature of melanic C. septempunctata might prolong their oviposition period and so increase fecundity, as suggested for A. bipunctata (Digby, 1955; Dixon, 1972; Muggleton et al., 1975; Stewart \& Dixon, 1989; De Jong et al., 1996). However, performance of the aulica phenotype of $H$. axyridis, measured in terms of consumption rate, larval biomass, longevity and reproduction is better than that of the nigra phenotype (Soares et al., 2001). As there were no significant differences in the percentage of eggs that hatched it appears that the males of both morphs were equally successful in fertilizing females.

The age-specific fecundity graphs reveal that typical females attain an earlier but lower peak of oviposition than melanic females. The earlier peak of typical females can be attributed to their relatively short oviposition period. Pre-oviposition period, start of oviposition, peak and subsequent decline in oviposition suggest that there are three stages in gonadal development, viz. maturation, maturity and senescence. The initial increase and subsequent decrease in oviposition suggest that female performance deteriorates with age. Thus, along with many other life history constraints, senescence also regulates the physiology of ladybirds (Srivastava \& Omkar, unpubl.).

The better reproductive performance of melanic females, associated with their preferred status as mates and higher levels of activity in the field (Muggleton, 1979) raise a paradox: why are they comparatively rare in nature? It is probable that melanic morphs have an advantage over typicals in terms of their more efficient absorption of solar radiation but this advantage may be counteracted by various combinations of other factors, including winter mortality, selective predation, number of generations per year, migration rate and the disadvantage of being melanic homozygous (Muggleton et al., 1975; Muggleton, 1978; O'Donald et al., 1984). Hence, it is possible that natural and sexual selection act to maintain a stable population of morphs in nature, which operates by the increased preference for and reproductive advantage of melanics. Differences in the microhabitats of the two morphs perhaps affect their rearing conditions and their performance is dependent on the interaction between their genotype and the environment.

The present study reveals: (1) Melanic mates were preferred over typical mates, (2) mate choice is more female than male dependent, (3) small males (melanic) have a mating advantage over large (typical) males, (4) melanic females had a reproductive advantage over typical females, in terms of a higher fecundity and egg viability, (5) percentage of egg hatch was not affected by morph, and (6) fecundity functions had a triangular shape with an earlier but lower peak in oviposition in typical than in melanic females and (7) the mate choice and performance of both morphs were dependent on the interaction between genotype and environment.

ACKNOWLEDGEMENTS. Authors are grateful to I. Hodek, Institute of Entomology, Czech Academy of Sciences, České Budějovice, Czech Republic; A.F.G. Dixon, University of East Anglia, Norwich, UK, for improving the draft and two anonymous reviewers for critically examining the manuscript and providing valuable suggestions. We thank G.G. Agarwal, Department of Statistics, University of Lucknow, Lucknow and S. Rajan, Scientist, Central Institute of Subtropical Horticulture (CISH), Lucknow, for their help with the statistical analysis. SS is also thankful to the Council of Scientific and Industrial Research, New Delhi for financial support (grant No. 9/107(231)/2002-EMR-I).

\section{REFERENCES}

BRAKefield P. M. 1984a: Ecological studies on the polymorphic ladybird Adalia bipunctata in The Netherlands. I. Population biology and geographical variation in melanism. J. Anim. Ecol. 53: 761-774.

BRAKEFIELD P.M. 1984b: Ecological studies on the polymorphic ladybird Adalia bipunctata in The Netherlands. II. Population dynamics, differential timing of reproduction and thermal melanism. J. Anim. Ecol. 53: 775-790.

BRAKEFIELD P.M. 1984c: Selection along cline in the ladybird Adalia bipunctata in The Netherlands: general mating advantage to melanics and its consequences. Heredity 53: 37-49.

BRaKefield P.M. \& Willmer P.G. 1985: The basis of thermal melanism in ladybird Adalia bipunctata: differences in the reflectance and thermal properties between the morphs. Heredity 54: 9-14.

CREED E.R. 1975: Melanism in the two spot ladybird: the nature and intensity of selection. Proc. R. Soc. Lond. (B) 190: 135-148.

DARWIN C. 1871: The Descent of Man and Selection in Relation to Sex. Murray, London.

De Jong P.W. \& Brakefield P.M. 1998: Climate and change inclines for melanism in two spot ladybird, Adalia bipunctata (Coleoptera: Coccinellidae). Proc. R. Soc. Lond. (B) 265 : 39-43.

De Jong P.W., Gussekloo S.W.S. \& Brakefield P.M. 1996: Differences in thermal balance, body temperature and activity between non-melanic and melanic two-spot ladybird beetles (Adalia bipunctata) under controlled conditions. J. Exp. Biol. 199: 2655-2666.

DigBY P.S.B. 1955: Factors affecting the temperature excess of insects in sunshine. J. Exp. Biol. 32: 279-298. 
Dixon A.F.G. 1972: Control and significance of the seasonal development of colour forms in the sycamore aphid, Drepanosiphum platanoides (Schr.). J. Anim. Ecol. 41: 689-697.

Dixon A.F.G. \& Agarwala B.K. 2002: Triangular fecundity function and ageing in ladybird beetles. Ecol. Entomol. 27: 433-440.

FISCHER R.A. 1930: The Genetical Theory of Natural Selection. Clarendon Press, Oxford, 354 pp.

Hansen T.F. \& Price D.K. 1995: Good genes and old genes. Do old mates provide superior genes? J. Evol. Biol. 8: 759-778.

Hemptinne J.-L., Lognay G. \& Dixon A.F.G. 1998: Mate recognition in the two-spot ladybird beetle, Adalia bipunctata: role of chemical and behavioural cues. J. Insect Physiol. 44: $1163-1171$.

Hodek I. \& Ceryngier P. 2000: Sexual activity in Coccinellidae (Coleoptera): a review. Eur. J. Entomol. 97: 449-456.

Hodek I. \& HonĚK A. 1996: Ecology of Coccinellidae. Kluwer Academic Publishers, Dordrecht, Boston, London, 464 pp.

Jennions M.D. \& Petrie M. 1997: Variation in mate choice and mating preferences: A review of causes and consequences. Biol. Rev. 72: 283-327.

Kearns P.W.E., Tomlinson I.P.M., O'Donald P. \& Veltman J.C. 1990: Non-random mating in the two spot ladybird (Adalia bipunctata): I. A reassessment of the evidence. Heredity 65: 229-240.

Kearns P.W.E., Tomlinson I.P.M., O’Donald P. \& Veltman J.C. 1992: Non-random mating in Adalia bipunctata (two spot ladybird). II. Further tests for female mating preference. Heredity 68: 385-389.

Kокко H. \& Lindstrom J. 1996: Evolution of female preference for old mates. Proc. R. Soc. Lond. (B) 263: 1533-1538.

Komai T. 1956: Genetics of lady-beetles. Adv. Genet. 8: $155-185$.

Lusis YA.YA. 1961: On the biological meaning of colour polymorphism of lady-beetle Adalia bipunctata L. Latv. Entomol. 4: 2-29.

MAJERUS M.E.N. 1997: Interspecific hybridisation in ladybirds (Col.: Coccinellidae). Entomol. Rec. 109: 11-23.

Majerus M.E.N., O’Donald P. \& Weir J. 1982a: Evidence for preferential mating in Adalia bipunctata. Heredity 49: 37-49.

Majerus M.E.N., O'Donald P. \& Weir J. 1982b: Female mating preference is genetic. Nature (London) 300: 521-523.

Merkel G. 1977: The effect of temperature and food quality on the larval development of Gryllus bimaculatus (Orthoptera, Gryllidae). Oecologia 30: 129-140.

Muggleton J. 1978: Selection against the melanic morphs of Adalia bipunctata (two-spot ladybird): a review and some new data. Heredity 40: 269-280.

Muggleton J. 1979: Non random mating in wild populations of polymorphic Adalia bipunctata. Heredity 42: 57-69.

Muggleton J., Lonsdale D. \& Benham B.R. 1975: Melanism in Adalia bipunctata L. (Col., Coccinellidae) and its relationship to atmospheric pollution. J. Appl. Ecol. 12: 465-471.

O’Donald P. \& Majerus M.E.N. 1984: Polymorphism of melanic ladybirds maintained by frequency-dependent sexual selection. Biol. J. Linn. Soc. 23: 101-111.

O’Donald P. \& Majerus M.E.N. 1985: Sexual selection and the evolution of preferential mating in ladybirds I. Selection for high and low lines of female preference. Heredity 55: 401-412.

O’Donald P., Derrick M., Majerus M.E.N. \& Weir J. 1984: Population genetic theory of the assortative mating, sexual selection and natural selection of the two-spot ladybird, Adalia bipunctata. Heredity 52: 43-61.

OMKAR \& Pervez A. 2002: Influence of temperature on the agespecific fecundity of a ladybird beetle, Micraspis discolor (Fabricius). Insect Sci. Applic. 22: 61-65.

OMKAR \& SRIVASTAVA S. 2002: The reproductive behaviour of an aphidophagous ladybird beetle, Coccinella septempunctata Linnaeus. Eur. J. Entomol. 99: 465-470.

Osawa N. \& Nishida T. 1992: Seasonal variation in elytral colour polymorphism in Harmonia axyridis (the ladybird beetle): the role of non-random mating. Heredity 69: 297-307.

Ponsonby D.J. \& Copland M.J.W. 1998: Environmental influences on fecundity, egg viability and egg cannibalism in the scale insect predator, Chilocorus nigritus. BioControl 43: $39-52$.

ProulX S.R. 2001: Female choice via indicator traits easily evolves in the face of recombination and migration. Evolution 55: 2401-2411.

RHAMHALINGHAN M. 1985: Intraspecific variation in ovariole number/ovary in Coccinella septempunctata L. (Coleoptera: Coccinellidae). Ind. Zool. 9: 91-97.

RHAMHALINGHAN M. 1987: Seasonal variation in ovariolar output in Coccinella septempunctata L. (Coleoptera: Coccinellidae). In Palanicchami S. (ed.): Proc. $5^{\text {th }}$ Indian Symposium Invert. Reprod. Dept. Zool., Arulmigu Palani Andavar, College of Arts and Culture, Palani, India, pp. 149-157.

Rothschild M. \& Lane C. 1962: A note on hibernating ladybirds. Proc. R. Entomol. Soc. Lond. (C) 27: 7.

SAKALUK S.K. \& Ivy T.M. 1999: Virgin male mating advantage in sagebrush cricket: differential male competitiveness or non independent mate choice? Behaviour 136: 1335-1346.

SakaluK S.K., Schaus J.M., Eggert A.E., Snedden W.A. \& BRADY P.L. 2002: Polyandry and success of offspring reared under varying nutritional stress in decorated crickets. Evolution 56: 1999-2007.

SAVAlli U.M. \& FoX C.W. 1999: The effect of male mating history on parental investment, fecundity and female remating in the seed beetle, Callosobruchus maculatus. Funct. Ecol. 13: 169-177.

Simmons L.W. 1987: Heritability of a male character chosen by females of the field cricket Gryllus bimaculatus. Behav. Ecol. Sociobiol. 21: 129-133.

Soares A.O., Coderre D. \& Schanderl H. 2001: Success of two phenotypes of Harmonia axyridis (Coleoptera: Coccinellidae). Eur. J. Entomol. 98: 287-293.

SRIVASTAVA S. \& OMKAR 2003: Scanning electron microscopy of antennae of Coccinella septempunctata (Coccinellidae: Coleoptera). Entomol. Sin. 10: 271-279.

Stewart L.A. \& Dixon A.F.G. 1989: Why big species of ladybird beetles are not melanic. Funct. Ecol. 3: 165-177.

THORNHILl R. \& Alcock J. 1983: The Evolution of Insect Mating Systems. Harvard University Press, Cambridge, MA, 564 pp.

Ueno H., Sato Y. \& Teuchida K. 1998: Color-associated mating success in a polymorphic ladybird beetle, Harmonia axyridis. Funct. Ecol. 12: 757-761.

WANG Q. 2002: Sexual selection of Zorion guttigerum Westwood (Coleoptera: Cerambycidae: Cerambycinae) in relation to body size and color. J. Insect Behav. 15: 675-687.

YASUDA H. \& Dixon A.F.G. 2002: Sexual size dimorphism in the two spot ladybird beetle Adalia bipunctata: developmental mechanism and its consequences for mating. Ecol. Entomol. 27: 493-498. 